\title{
Taenioides kentalleni, a new species of eel goby from Saudi Arabia (Gobiidae: Amblyopinae)
}

\author{
EDWARD O. MURDY ${ }^{1} \&$ JOHN E. RANDALL ${ }^{2}$ \\ ${ }^{1}$ National Science Foundation, 4201 Wilson Blvd., Arlington, VA 22230, USA \\ ${ }^{2}$ Bishop Museum, 1525 Bernice St., Honolulu, HI 96817-2704 USA
}

\begin{abstract}
A new species of eel goby, Taenioides kentalleni, is described on the basis of a single specimen from Ras Az Zawr, Jubail, Saudi Arabia. It differs from other species of Taenioides by the following combination of characters: 35 caudal vertebrae; 72 dorsal-fin elements, 65 anal-fin elements, median fins edged in black and the caudal fin almost entirely black. This species is figured and compared with other nominal species of Taenioides.
\end{abstract}

Key words: eel goby, Taenioides, Amblyopinae, Gobiidae, new species

\section{Introduction}

Gobies of the genus Taenioides (Gobiidae: Amblyopinae) are also known as eel gobies, which alludes to their attenuated body shape. Eel gobies are burrowers in intertidal areas and mangrove swamps from the east coast of Africa eastward to Fiji. Due to their burrowing habits, specimens of Taenioides are not common in collections and individuals are normally not observed or caught by fishers. Taenioides is diagnosed among Gobiidae by its possession of a Y-shaped, second anal fin pterygiophore (Birdsong et al. 1988). In 1998, a single specimen of Taenioides not fitting any published descriptive account was collected from an exposed mudflat on the east coast of Saudi Arabia at Ras Az Zawr Bay by Kent Allen, who spent much time searching for additional specimens in the same area without success. The objective of this paper is to describe this species as new and compare it with congeners.

Methods for counts and measurements followed Murdy and Shibukawa (2001). The methods of Birdsong et al. (1988) were used in describing the relationship between the spinous dorsal fin pterygiophores and the underlying vertebrae. Institutional abbreviations are as listed in Leviton et al. (1985). Standard length (SL) is used throughout. 
Holotype: USNM 365692, 198.2mm SL, female, collected 14 January 1998 at Ras Az Zawr Bay, north of Jubail, Kingdom of Saudi Arabia.

Diagnosis. A species of Taenioides with a long and slender body (body depth/SL = $4 \%$ ), total dorsal-fin elements 72 , anal-fin elements 65 , and caudal vertebrae 35 . Second dorsal and anal fins edged in black, caudal fin almost entirely black.

Description. Total dorsal-fin elements 72 ; first and second dorsal fins continous; first dorsal fin with six flexible spines; all rays of second dorsal fin segmented and branched; dorsal-fin base long and broadly joined with caudal fin. Total anal-fin rays 65 , all segmented and branched; anal-fin height slightly less than second dorsal-fin height; anal-fin membrane narrowly joined with caudal fin. Pectoral fin with 20-21 rays, rounded posteriorly, pectoral-fin length $36 \%$ of pelvic-fin length; all pectoral-fin rays segmented and most are branched. Pelvic-fin rays I, 5, with well developed frenum and connecting membrane forming cup-shaped disc. Caudal fin very short, representing less than 5\% of total length.

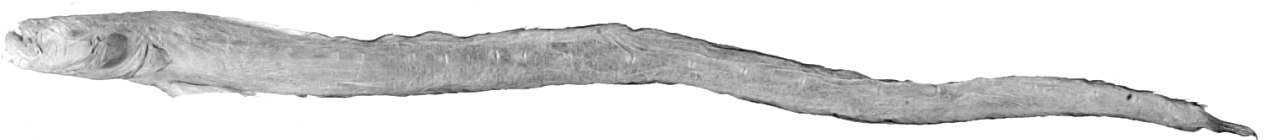

FIGURE 1. Taenioides kentalleni, sp. nov., USNM 365692, holotype, female, $198.2 \mathrm{~mm}$ SL, Ras Az Zawr, Saudi Arabia (image by S. Raredon).

Head and body compressed. Scales absent on both head and body. Teeth in outermost row of jaws enlarged, sharp and pointed; when mouth closed, outermost teeth interlock. Upper and lower jaws with 2 rows of teeth posterolaterally and 3-4 rows anteromedially. No caninoid teeth internal to symphysis of lower jaw. Outer-row teeth larger than teeth of inner row(s); outer row teeth of lower jaw longer than those of upper-jaw; 12 teeth in outer row of upper jaw; 9 teeth in outer row of lower jaw. No palatine nor vomerine teeth present.

Mouth large and almost vertical. Tongue thick. Isthmus narrow.

Eye rudimentary, but distinct, covered by skin.

Cephalic sensory canals and pores absent. Papillae on head located on raised dermal folds. Twenty-five vertical rows of papillae, some paired, extend from the pectoral-fin base to the caudal peduncle.

Five pairs of short, thin barbels on ventral surface of head. Spinous dorsal-fin pterygiophore formula 3-12210; Y-shaped, second anal fin pterygiophore present. Precaudal vertebrae 10 , caudal vertebrae 35 . 
TABLE 1. Nominal species of Taenioides with selected meristic values.

\begin{tabular}{|c|c|c|c|c|c|c|}
\hline Nominal species & $\begin{array}{c}\text { Type } \\
\text { locality }\end{array}$ & $\begin{array}{c}\text { Type } \\
\text { material }\end{array}$ & $\begin{array}{l}\text { Total dorsal- } \\
\text { fin elements }\end{array}$ & $\begin{array}{l}\text { Total anal- } \\
\text { fin elements }\end{array}$ & $\begin{array}{c}\text { Total } \\
\text { vertebrae }\end{array}$ & Source \\
\hline anguillaris Linnaeus 1758 & China & ZIU 185 & 51 & 43 & 30 & R.T.* \\
\hline hermannii Lacepède 1800 & $\begin{array}{l}\text { Chinese } \\
\text { painting }\end{array}$ & none & unknown & unknown & unknown & O.D.* \\
\hline coecula Bloch \& Schneider 1801 & $\begin{array}{l}\text { Tranquebar, } \\
\text { India }\end{array}$ & unknown & 50 & 43 & - & O.D.* \\
\hline gracilis Valenciennes 1837 & $\begin{array}{l}\text { Pondicherry, } \\
\text { India }\end{array}$ & $\begin{array}{l}\text { MNHN } \\
\text { A.1865 }\end{array}$ & 54 & 48 & 29 & R.T.* \\
\hline rugosus Richardson 1846 & China & none & 45 & 40 & - & O.D.* \\
\hline eruptionis Bleeker 1849 & $\begin{array}{c}\text { Java, } \\
\text { Indonesia }\end{array}$ & $\begin{array}{c}\text { RMNH } \\
4806\end{array}$ & 56 & 48 & 29 & R.T.* \\
\hline cirratus Blyth 1860 & $\begin{array}{l}\text { Calcutta, } \\
\text { India }\end{array}$ & unknown & 47 & 44 & - & O.D.* \\
\hline brachygaster Günther 1861 & East Indies & $\begin{array}{c}\text { BMNH } \\
1852.9 .13 .233\end{array}$ & 51 & 46 & 27 & R.T.* \\
\hline mordax DeVis 1883 & $\begin{array}{c}\text { Queensland, } \\
\text { Australia }\end{array}$ & QM I.81 & 48 & 40 & 28 & R.T.* \\
\hline purperascens DeVis 1884 & $\begin{array}{l}\text { Brisbane, } \\
\text { Australia }\end{array}$ & unknown & 43 & 36 & - & O.D.* \\
\hline snyderi Jordan \& Hubbs 1925 & $\begin{array}{c}\text { Fukuoka, } \\
\text { Japan }\end{array}$ & CAS 106638 & 54 & 47 & 32 & R.T.* \\
\hline caniscapulus Roxas \& Ablan 1938 & $\begin{array}{c}\text { Negros, } \\
\text { Philippines }\end{array}$ & lost & 48 & 41 & - & O.D.* \\
\hline esquivel Smith 1947 & Mozambique & RUSI 261 & 54 & 48 & 29 & R.T.* \\
\hline
\end{tabular}

$*$ R.T. $=$ Radiograph of type; O.D.= Original description

Selected morphometric measurements are as follows: SL/total length $=0.951$; head length $(\mathrm{HL}) / \mathrm{SL}=0.121$; pelvic-fin length $(\mathrm{PEL}) / \mathrm{SL}=0.070 ; \mathrm{PEL} / \mathrm{HL}=0.575$; pectoralfin length $(\mathrm{PEC}) / \mathrm{SL}=0.026 ; \mathrm{PEC} / \mathrm{HL}=0.209 ; \mathrm{PEC} / \mathrm{PEL}=0.363$; head width $/ \mathrm{SL}=0.050$; snout length $/ \mathrm{SL}=0.025$; jaw length $/ \mathrm{SL}=0.030$; interorbital width $/ \mathrm{SL}=0.018$; nape width/SL $=0.042$; body depth/SL $=0.040 ;$ predorsal length $/ \mathrm{SL}=0.157$; prepelvic length $\mathrm{SL}=0.144 ;$ and preanal length $/ \mathrm{SL}=0.250$.

Coloration. Based on a color photograph of the only specimen after it had been collected, head and body bluish gray, darker posteriorly. No markings on head or body. Spinous dorsal fin translucent. Distal margin of soft dorsal and anal fins black with blackened area increasing posteriorly on both fins. Black continuing onto caudal fin with only a 
small basal portion of the caudal fin not being black. Basal portions of pectoral and pelvic fins yellowish, remainder of fins translucent.

Distribution. Type and only known locality is Ras Az Zawr Bay, north of Gulf coast of Jubail, Saudi Arabia. Holotype was collected at the mouth of its burrow on a tidally exposed mudflat.

Etymology. This species is named for Kent Allen, who collected and photographed the only known specimen.

Comparison with congeners. Taenioides is in need of revision. As such, we are aware of 13 nominal species that conform to the definition of Taenioides (Birdsong et al. 1988) and none of them has been recorded from the Arabian Gulf (Kuronuma and Abe, 1986 and Table 1). Of these 13 nominal species, published information on selected meristic counts exists for 11 of them, and type specimens were available for seven. Radiographs were made and examined for the seven type specimens. We note that neither published data nor type material exists for $T$. hermannii Lacepède (1800), which was synonymized with $T$. anguillaris (Linnaeus 1758) by Koumans (1953) and Bauchot et al. (1991).

Based on published data and/or data gleaned from radiographs of type specimens, $T$. kentalleni has greater numbers of dorsal- and anal-fin elements, and vertebrae $(72,65$, and 45 , respectively) than any of the nominal species of Taenioides for which we have data. With respect to the number of total dorsal-fin elements, the type of T. eruptionis (RMNH 4806) comes closest to $T$. kentalleni with 56 total dorsal-fin elements (16 fewer than $T$. kentalleni); all other nominal species have 51 or fewer. For total anal-fin elements, T. eruptionis, T. esquivel (holotype, RUSI 261) and T. gracilis (holotype, MNHN A.1465) come closest to T. kentalleni (65) with 48; all other nominal species have 47 or fewer. For total vertebrae, the paralectotype of T. snyderi (CAS 106638) has 32, 13 fewer than T. kentalleni; all other nominal species have 30 or fewer. As the numbers of dorsal- and anal-fin elements, and vertebrae in T. kentalleni differ markedly from the other nominal species of Taenioides, we believe it is appropriate to recognize T. kentalleni as a valid species of Taenioides even though we have only a single specimen and the genus is unresolved with respect to its constituent species.

\section{Acknowledgments}

Numerous individuals aided this study, for their assistance we are grateful: D. Catania and C.J. Ferraris (CAS), M. Eriksson (ZIU), P. Heemstra (RUSI), J. Johnson (QM), S. Kullander (NRM), P. Campbell (BMNH), M. van Oijen (RMNH), P. Pruvost (MNHN), J. Clayton and S. Raredon (USNM). 
Bauchot, M.-L., Desoutter, M., Hoese, D.F. \& Larson, H.K. (1991) Catalogue critique des types de Poissons du Muséum National d'Histoire Naturelle. (Suite) Sous-ordre des Gobioidei. Bulletin de Muséum National d'Histoire Naturelle, 13, 1-82.

Birdsong, R.S., Murdy, E.O. \& Pezold, F.L. (1988) A study of the vertebral column and median fin osteology in gobioid fishes with comments on gobioid relationships. Bulletin of Marine Science, 42:174-215.

Bleeker, P. (1849) Bijdrage tot de kennis der Blennioïden en Gobioïden van der Soenda-Molukschen Archipel, met beschrijving van 42 nieuwe soorten. Verhandelingen van het Bataviassch Genootschap, 22(6), 1-40.

Bloch, M. E. \& Schneider, J.G. (1801) Systema Ichthyologiae Iconibus Cx Illustratum. Post Obitum Auctoris Opus Inchoatum Absolvit, Correxit, Interpolavit Jo. Gottlob Schneider, Saxo. Berolini. Sumtibus Austoris Impressum et Bibliopolio Sanderiano Commissum, Berlin. 584 pp., 110 pls.

Blyth, E. (1860) Report on some fishes received chiefly from the Sitang River and its tributary streams, Tenasserim Provinces. Journal of the Asiatic Society of Bengal, 29, 138-174.

De Vis, C. W. (1883) Description of new genera and species of Australian fishes. Proceedings of the Linnaean Society of New South Wales, 8, 283-289.

De Vis, C. W. (1884) New fishes in the Queensland Museum. Proceedings of the Linnaean Society of New South Wales, 9, 685-698.

Günther, A. C. L.G. (1861) Catalogue of the Acanthopterygian Fishes in the Collection of the British Museum. Volume 3. London, 586 pp.

Jordan, D. S. \& Hubbs, C.L. (1925) Record of fishes obtained by David Starr Jordan in Japan, 1922. Memoirs of the Carnegie Museum, 10, 93-346.

Koumans, F. P. (1953) Gobioidea. In: Weber and de Beaufort. Fishes of the Indo-Australian Archipelago. Volume 10. E. J. Brill, Leiden, The Netherlands, 423 pp.

Kuronuma K. \& Abe, Y. (1986). Fishes of the Arabian Gulf. Kuwait Institute for Scientific Research, Kuwait City, State of Kuwait. 356 pp.

Lacepède, B.G. E. (1800) Histoire Naturelle des Poissons. Volume 2. Paris, 632 pp.

Leviton, A.E., Gibbs, R.H., Heal, E. \& Dawson, C.E. (1985) Standards in herpetology and ichthyology: part 1. Standard symbolic codes for institutional resource collections in herpetology and ichthyology. Copeia, 1985, 802-832.

Linnaeus, C. (1758) Systema Naturae, Ed. X. (Systema naturae per regna tria naturae, secundum classes, ordines, genera, species, cum characteribus, differentiis, synonymis, locis. Tomus I. Editio decima, reformata.) Holmiae. 824 pp.

Murdy, E.O. \& Shibukawa, K. (2001) A revision of the gobiid fish genus Odontamblyopus (Gobiidae: Amblyopinae). Ichthyological Research, 48 (2001) 1, 31-43.

Richardson, J. (1846) Report on the ichthyology of the seas of China and Japan. Report of the British Association for the Advancement of Science, 15th meeting [1845], 187-320.

Roxas, H. A. \& Ablan, G.L. (1938) A new taenioid fish from Occidental Negros. Philippine Journal of Science, 66 (no. 2), 261-265, Pls. 1-2. 
Smith, J. L. B. (1947) New species and new records of fishes from South Africa. Annals and Magazine of Natural History, 13, 793-821.

Valenciennes, A. in Cuvier, G. \& Valenciennes, A. (1837) Histoire Naturelle des Poissons. Tome douzième. Suite du livre quatorzième. Gobioïdes. Livre quinzième. Acanthoptérygiens à pectorales pédiculées. Paris, 507 pp. 